\title{
High Resolution Chemostratigraphy of Earth's Earliest Carbonate Platform, Red Lake Greenstone Belt, Ontario, Canada
}

\author{
M. AfroZ ${ }^{1}$, P. FralicK ${ }^{2}$, L.PATRY ${ }^{1}$, AND S.V. LALONDE ${ }^{1}$ \\ ${ }^{1}$ CNRS-UMR6538 Géosciences Océan, IUEM, 29280 \\ Plouzané, France (*correspondence: munira.afroz@univ- \\ brest.fr) \\ ${ }^{2}$ Department of Geology, Lakehead University, Thunder Bay, \\ ON P7B 5E1 Canada
}

The Red Lake Greenstone Belt (RLGB) belongs to the Ball Assemblage of the Uchi Subprovince of the Archean Superior Province in northwestern Ontario, Canada. It contains Earth's earliest known large accumulation of carbonate ( $>200 \mathrm{~m}$ thick) and was deposited between 2.940 to $2.925 \mathrm{Ga}$ ago [1]. The Ball assemblage is composed of various types of chemical and siliciclastic metasedimentary rocks. Based on field investigations and analyses of multiple industry drill cores, this study explores the stratigraphy and major and trace element geochemistry of a 400 m-thick succession that is composed primarily of stromatolitic carbonate and sandstone along with deeper water sedimentary facies including oxide facies iron formation, chert, sulfidic shale, and black shale. High-resolution XRF scanning was completed for five drill cores ( $>650 \mathrm{~m}$ total) using an Avaatech core scanner at IFREMER (Brest, France) to obtain continuous records of major and trace elements intensities throughout the different lithologies. The elemental concentrations of different lithofacies were calibrated based on bulk rock acid digestion using the log-ratio calibration model of the AvaaXelerate program [2]. The high-resolution chemostratigraphy distinctly differentiates the composition of carbonates (calcite and dolomite) and reveals several sulfiderich zones, manganese enrichments, and siliciclastic intervals. The chemostratigraphic record also displays the geochemical transition from one facies to another and siliciclastic interference during precipitation of carbonate and iron formation facies. Our data reveal multiple phases of carbonate deposition punctuated by sedimentation of siliciclastic and deeper water facies. Disseminated and nodular sulfide enrichment in black shale implies that sulfidic conditions might have prevailed in the deeper part of the basin while manganese enrichment points to fluctuating basinal redox conditions.

[1] Corfu \& Wallace (1986) Can. J. Earth Sci. 23, 27-42. [2] Welje \& Tjallingii (2008) Earth Planet. Sci. Lett. 274, 423438. 